Partial intersubjectivity and sufficient understandings for current practical purposes : On a specialized practice in Swedish conversation

\author{
Linell, Per
}

2016-10-01

Linell , P \& Lindström , J K 2016 , ' Partial intersubjectivity and sufficient understandings for current practical purposes : On a specialized practice in Swedish conversation ' , Nordic journal of linguistics, vol. 39 , no. 2 , pp. 113-133 . https://doi.org/10.1017/S0332586516000081

http://hdl.handle.net/10138/175072

https://doi.org/10.1017/S0332586516000081

unspecified

acceptedVersion

Downloaded from Helda, University of Helsinki institutional repository.

This is an electronic reprint of the original article.

This reprint may differ from the original in pagination and typographic detail.

Please cite the original version. 
Linell, Per \& Jan Lindström. 2016. Partial intersubjectivity and sufficient understandings for current practical purposes: on a specialized practice in Swedish conversation. Nordic Journal of Linguistics 39(2), 113-133. (Authors' accepted manuscript)

\title{
Partial intersubjectivity and sufficient understandings for current practical purposes: on a specialized practice in Swedish conversation
}

\section{Per Linell \& Jan Lindström}

\begin{abstract}
This paper explores issues of intersubjectivity and shared understanding as they arise in dyadic spoken interaction. Using data from Swedish conversations, we approach the topic by focusing on the functions of a reactive construction that occurs in situations when a linguistic expression $(x)$ has been used in a prior utterance, and this expression is found to be only partially acceptable in the situation at hand. It is therefore reacted to by one of the interlocutors, and negotiated in a new turn initiated by $x$ - $\stackrel{a}{a}-x$, i.e., a unit in which two identical copies of $x$ are conjoined by å 'and', and then expanded by a supporting argument. The pragmatic functions of the construction include that of suggesting a sufficient clarification of what should be a reasonable situated meaning and an intersubjective basis for ensuing talk.
\end{abstract}

\section{KEYWORDS}

Intersubjectivity, subjectivity, conversation, social interaction, Swedish, sufficient clarification and understanding, reactive construction, $x$ - $\stackrel{a}{-}-x$.

\author{
ADDRESSES \\ Per Linell, Professor Emeritus, Department of Education, Communication and Learning, \\ Göteborg University, P.O. Box 300, SE-40530 Göteborg, Sweden \\ e-mail: per.linell@gu.se \\ Jan Lindström, Professor, Department of Finnish, Finno-Ugrian and Scandinavian Studies, \\ University of Helsinki, P.O. Box 24, FIN-00014 Helsinki University, Finland \\ e-mail: jan.k.lindstrom@helsinki.fi
}




\section{INTRODUCTION}

In this paper we will discuss aspects of sense-making in dialogical interaction, more specifically conversations and other spoken exchanges. This focus will entail an interest in intersubjectivity, that is, shared, or as we will argue, partially shared attention, understandings and stances on the part of interlocutors. Interactivities ${ }^{1}$ are the dialogical bedrock of intersubjectivity in the sense that action precedes knowledge, and this is primary to the development and maintenance of both objectivity and subjectivity. We will not go further into these abstract considerations, but instead deal with the role of language and dialogue, and more precisely the use of a specific conversational practice in Swedish and related languages, the $x-\stackrel{a}{a}-x$ construction, arguably deployed by participants in negotiating situated intersubjectivity.

Interaction analysts, for example, within Conversation Analysis (Schegloff 1991, 1992), usually assume that parties to interaction are engaged in trying to achieve "socially shared cognition”. But people seldom reach such a goal in mundane interactions. There is overwhelming evidence that owing to their incongruent "system of relevances", people can only achieve partially shared understandings, what Schütz (1962:11-12; cf. also Garfinkel 1967; Heritage 1984) has called "sufficient understandings" for "current practical purposes". We will argue that this is a more realistic conception of human intersubjectivities.

\section{NEGOTIATIONS OF SHARED UNDERSTANDING BY MEANS OF A REACTIVE CONSTRUCTION}

In a very general sense people use their conversations for - among other things - negotiating shared understandings of situations and topics. However, this is often done only implicitly and allusively; as long as the verbal interchange evolves relatively smoothly, participants do not engage in metalinguistic commentaries or repair. But when common understandings seem 
to be at risk, they do indulge in repair (Schegloff 1979, 1992; Couper-Kuhlen and Thompson 2005). In our case we will examine a particular conversational resource in Swedish which has some links to repair, the $x$ - $\stackrel{a}{-}-x$ construction. This construction occurs in situations where a linguistic expression $(x)$ has been used in a prior utterance, either other-responsively, when the prior utterance has been produced by another speaker, or self-responsively, when that utterance was the speaker's own. ${ }^{2}$ The incoming speaker finds the expression $x$ to be only partially acceptable in the situation at hand; this $x$ is therefore reacted to and negotiated in a turn which is initiated by $x$-å-x, i.e., a unit in which two identical $x$ 's are conjoined by the additive coordinator $\stackrel{a}{a}[\supset]$ 'and' (spelled $<$ och $>$ in the written standard), and then further elaborated with supporting arguments in a turn-part what we will call an expansion.

For a start, let us give a simple example of other-responsive $x$ - $\stackrel{a}{a}-x$, drawn from a short narrative about a German family who lived in Finland (in a place called Träskberg) but found themselves forced to leave the country after the war because German property was confiscated (lines 1,5$)$. The narrator, G, uses the verb flytta 'move' in line 6 when he refers to the family's return to Germany:

(1) FLYTTA Å FLYTTA (SAM:V1). (Conversation between six young men who are eating and drinking together) ${ }^{3}$
1. G: dom bodde
2. står nu [å, stand-PRS now and 'now stands and'
they live-PST there up on
'they lived up there on (0.8) where Träskberg'
3. ?: $\quad\left[{ }^{\circ} \grave{j a ̊}^{\circ}\right.$ yeah
4. $\quad(0.8)$
5. G: sen så beslagtos huse å,
then PRT confiscate.PST-PASS house-DEF and

(0.8) var Träskberg 
'then the house was confiscated and'

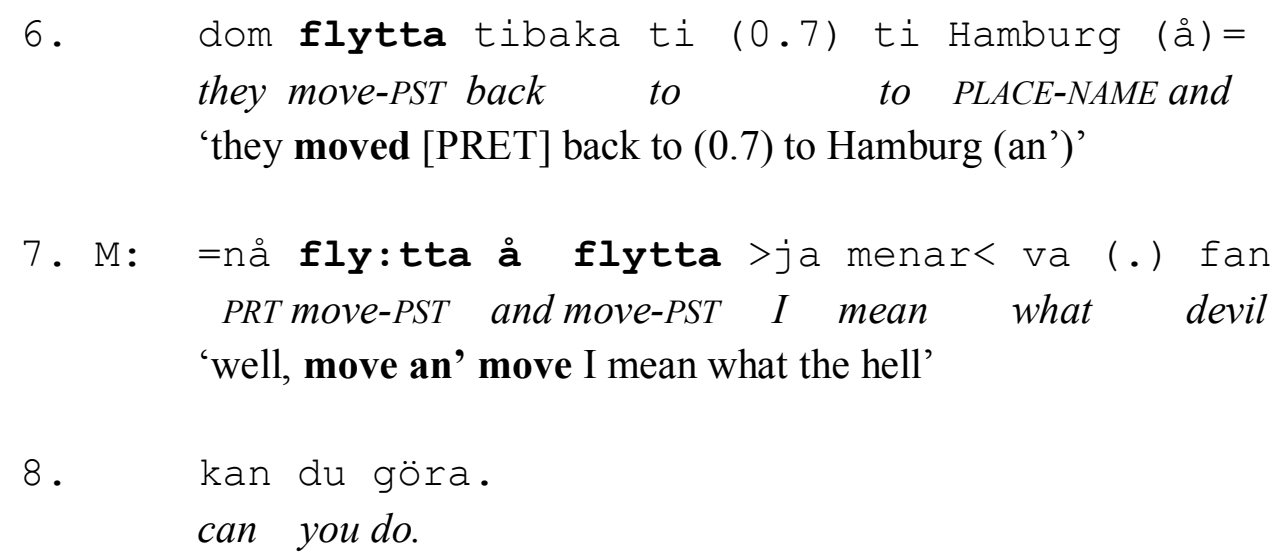

The first segment of the response turn in line $7, x \stackrel{a}{a} x$, contains the variable element $x$ which thus occurs twice. The $x$ in this example is the verb flytta, which causes a controversy on how to describe the situation at hand. Speaker M responds in line 7 with a turn which is prefaced by the particle nå, which is typical of dispreferred or non-straightforward answers, and the unit flytta a flytta. This turn-initial material is followed by ja menar 'I mean', leading into a somewhat more substantial contribution, the affective and resigned question va fan kan $d u$ göra 'what the hell can you do?'.

The coordinating $x$ - $\stackrel{a}{-}-x$ format suggests in an iconic way that there is more than just one understanding of ' $x$ ', in (1) a neutral sense of moving house of one's free will and a sense which may entail a meaning of running away because of exigent conditions. Thus, the response focuses on a possible lack of intersubjectivity and a possible breach in agreement between the participants at this specific point of interaction, and it especially stresses that $\mathrm{M}$ has a subjective perspective on the matter, or at least on G's word choice - a perspective which $\mathrm{G}$ is made aware of with the $x$ - $\stackrel{a}{-}-x$ move. However, $M$ does not really explain why flytta is controversial, he merely hints at it by pointing out that the family did not have a choice in the situation. After line 8, the participants start talking about other things, thereby abandoning the previous topic. This abrupt closing is rather typical of $x-\stackrel{a}{-}-x$ events; they do seldom evolve into lengthy argumentations. 
In this paper we will discuss $x$ - $\stackrel{a}{-} x$ with respect to (partial) intersubjectivity and (partially) shared understandings between interlocutors involved in conversations. We will focus on examples in which these aspects are made more explicit than in Extract 1, i.e., when the expansion part following the $x$ - $\stackrel{a}{-}-x$ segment itself is more elaborated and hence provide more insight into the speaker's stances. The remainder of the paper will have the following outline. In Section 3 we will summarize some main points from earlier research on $x$ - $\stackrel{a}{-}-x$. After that (Section 4) we will account for our data and formulate our research questions in more detail. The discussion in Section 5 will attend to the fact that intersubjectivity can be partial both between and within individual participants. The study of interactivity will therefore shed light also on split ideas within individuals. In Section 6 we summarize and develop our conclusions about intersubjectivity and subjectivity.

\section{PRIOR RESEARCH ON THE CONSTRUCTION}

The $x$ - $\stackrel{a}{-} x$ construction and its contexts have been extensively researched earlier by the authors of this paper. These studies have mainly concerned the usage in Swedish (Lindström 1999, 2006; Lindström \& Linell 2007; Norén \& Linell 2007; Linell 2009b; Linell \& Mertzlufft 2014), but the same expressive pattern has been noted in reference grammars and dictionaries of Danish, Norwegian and Finnish. Further, $x$-and- $x$ as a conversational practice has been attested in Icelandic and Swedish-influenced Estonian (for details, see Lindström \& Linell 2007). In a study of German, Finkbeiner (2012) showed that a corresponding pattern ( $x$-und-x) occurs in electronic discussion forums, but the construction is not attested in spoken German data. The languages above are Scandinavian or spoken in the Circum-Baltic region, which suggests that this particular reactive construction is an areal phenomenon.

$X$ - $\stackrel{a}{-x} x$ has features of a "classical”, functionally specific grammatical construction (Fried \& Östman 2005), with slots for variable elements $(x)$ and a frame containing an obligatory 
lexical item ( $\stackrel{a}{a}$ 'and'). The meaning of this constructional pattern is not transparent from its constituent parts, which is why it could be called a formal idiom in the same manner as the English the X-er, the Y-er construction, e.g. the sooner, the better (Fillmore et al. 1988). The coordination of two identical copies of $x$, like in flytta a flytta ('move and move') (1), is to be interpreted in an asymmetrical, distributive way, i.e. it involves different kinds of $x$ rather than the same kind (compare constructions like there are teachers and teachers). ${ }^{4}$

As already mentioned, the construction $x$ - $\stackrel{a}{-}-x$ consists of two parts: (a) the $x$ - $\stackrel{a}{-}-x$ segment itself and (b) a following expansion which typically has a clausal form or consists of several turn-constructional units. The initial $x$ - $\stackrel{a}{-} x$ segment is not integrated in any clausal syntax but stands in a pre-front-field position, sometimes preceded by a discourse marker (like $n a ̊, j a$, allså 'well'). ${ }^{5}$ The expansion should be considered a more or less obligatory part of the whole construction (Lindström and Linell 2007). ${ }^{6}$ Its main function is to concede that $x$ is not completely inappropriate in the given situation but that it is not entirely acceptable either. It alludes to the fact that the meaning potential of $x$ (as a lexical resource) has several semantic aspects, and not all of these are relevant or applicable in the given situation (Norén and Linell 2007). Thus, the construction is not used to directly resist or challenge the wordings of a prior speaker, as some forms of repeat-prefacing answers do (see Bolden 2009); rather, the speaker who produces $x$ - $\stackrel{a}{-}-x$ points out that understandings regarding a specific characterization $(x)$ may be divided and must therefore be negotiated in the interactional context of use.

The responsive characteristic of the construction means that it can only occur in second position to a prior utterance or turn. The prior unit is typically a question, or sometimes a statement like in (1), that contains the expression of $x$. Often it concerns a matter of which the recipient (the one who comes up with the $x-\stackrel{a}{a}-x$ response) may be expected to have first-hand knowledge, i.e., from the point of the prior speaker, it is a B-event in the sense of Labov \& Fanshel (1977). 
The $x$ in the construction can evidently be of virtually any grammatical category, but it is most typically just one word (Lindström and Linell 2007). The $x$ is repeated either in exactly the same form as in the source utterance, or in an uninflected, paradigmatic base form (which may suggest a more abstract treatment of the repeated item). As already noted, $x \stackrel{a}{x}$ is often preceded by a particle, typically ja or nå (the latter in Finland Swedish) or a discourse marker like allså, which all signal that a non-straightforward response is forthcoming (cf. well in English and ben in French). The transition to the expansion is usually marked with the adversative conjunction men 'but' and occasionally with the discourse marker ja menar 'I mean' which signal a contrast or a complication. In prosodic terms, the $x$-åa- $x$ segment and the expansion are disjunct; the two $x$ 's are both stressed, sometimes with some extra prominence on the second conjunct (Lindström and Linell 2007:64-66).

The construction occurs across the board in colloquial or relatively colloquial registers in Swedish spoken language but also in the written medium, especially in interactional electronic discourse and literary dialogue. Prior studies of $x$ - $\stackrel{a}{-}-x$ have accounted for this construction's interactional-grammatical properties. For example, Lindström (1999) deals with $x$ - $\stackrel{a}{-}-x$ in relation to other reduplicative expressions, Linell (2009b) argues for the status of $x-\stackrel{a}{-}-x$ as a grammatical construction (in a technical sense), Lindström and Linell (2007) accounts for the grammar of $x$ - $\stackrel{a}{-}-x$ and its other- and self-responsive variants in conversation, Norén and Linell (2007) view $x$ - $\stackrel{a}{-} x$ as a participants' resource for exploring the meaning potentials of words (the ones occurring as $x$ ), and Linell and Mertzlufft (2014) discusses $x$ - $\stackrel{a}{a}-x$ in relation to other reactive constructions in Swedish and German. However, the topic of this paper, i.e., the ramifications of $x$ - $\stackrel{a}{-} x$ for issues of intersubjectivity, have not been highlighted anywhere else.

\section{DATA AND RESEARCH QUESTIONS}


Three of the four excerpts to be analysed in this paper are drawn from a series of talk-shows (called Min sanning 'My truth') broadcast by the Swedish (State) Television in 2014, and they come from one single show. The series was marketed with the slogan en gäst, ett samtal, en timme ("one guest, one conversation, one hour"). Each show is devoted to one interviewee, usually a well-known public figure, often a politician, artist or business person, who has withdrawn from his or her previous post(s). The interviewer asks quite a number of provocative questions, which might serve as elicitors of problematizing responses, sometimes involving $x-\stackrel{a}{-}-x$ with comparatively long expansions. Clearly, the talk-shows belong to a genre (Luckmann 2002) or activity type (Levinson 1979) that is different from many other speech exchanges, both private conversations and broadcast news interviews (note, however, that the shows are marketed as "conversations"). ${ }^{7}$ (Our fourth example, (5), also comes from a televised interview within the same genre.) Seen in relation to our entire collection of about 50 recorded authentic occurrences of $x$ - $\stackrel{\circ}{-}-x$ in their sequential contexts (see other publications cited above), which is mainly drawn from private conversations (e.g. Extract 1 above), professional-client exchanges (e.g. police interrogations and school contexts), and brief radio and television interviews, the talk-show data tend to be slightly deviant, in that they involve expanded sections of arguments and concessions after the $x$-å-x segment, something which is a minority feature in the collection as a whole. It is the expansions that give us an opportunity to analyze the participants' navigations in the intersubjective problematic.

We look upon the present article as a study of how intersubjectivities are achieved (or not achieved) in interactivities in conversation. A more specific research question concerns the role of $x$ - $\stackrel{a}{-} x$ as a discursive resource for making inferrable understandings more precise, but in particular for showing that understandings are oftentimes divided and can only be partially, rather than completely, shared. 
Our study is based on a qualitative analysis of a few episodes from the same kind of interview genre. One may therefore raise doubts about generalizability. However, we have extensive evidence from other studies of $x-\stackrel{a}{-}-x$ (that for obvious reasons could not be repeated here $)^{8}$, and we can testify to the fact that the talk-show data are not different from other data, as far as $x-\stackrel{a}{a}-x$ is concerned, except for one possible point, namely, that they involve longer expansions of arguments. This feature was the main reason for choosing these data for this paper on intersubjectivity, as the longer argumentations open a wider window to the interactional dynamics of the $x-\stackrel{a}{a}-x$ events.

\section{ANALYSIS}

The first three of our examples come from a recording of one and the same talk-show, in which a well-known Swedish politician is interviewed about his professional and personal life. Despite the fact that the show is part of public media, we have chosen to anonymize some aspects of the data. For example, the main character in Extracts $2-4$ has been given the fictive name Lars Svensson.

The talk-show is about 57 minutes long, and Svensson is of course the person who talks for most of the time (the other participant is a well-known female political journalist whom we here call Lotta Rosenberg). During the show, Svensson uses $x$ - $\stackrel{a}{-}-x$ three times. In two of the cases $(2,3)$ the problematised expressions deal with verbs for activities of speaking, tala 'speak, talk' and prata 'talk, speak'. Just before entering in Extract 2, the parties have talked about the fact that $\mathrm{S}$ is constantly active, among other things, with authoring books. In line 1 then, the interviewer $(R)$ presents yet another example of S's many interests: "you can speak a host of languages".

(2) TALA Å TALA (TV talk-show with a well-known politician, S, and an interviewer R) 
1. R: å så kan du tạla massa språk, va e de? åtta? and so can you speak mass language.PL what is it eight 'and then you can speak a host of languages, how many is it? eight?'

2. S: tạla å tậla (.) ja kan nj an:vända en ett sådär åtta speak and speak I can use one one like.that eight 'speak and speak, (.) I can nj- use some like eight'

3. tietal språk ${ }^{\circ}$ ja. ${ }^{\circ}$

ten-count language.PL yes

'some ten languages, yeah.'

4. R: vikket håller du på å lära dej nu?

which hold-PRS you on to learn REFL now

'which one are you busy learning now?'

5. S: ja håller faktist på me kinesiska men de har ja

I hold-PRS actually on with Chinese but that have I 'actually I am busy with Chinese but I have'

6. hållit på me i nästan tie år, å de e ett hold-SUP on with in almost ten year.PL and it is a 'been working on it for almost ten years, an' it is a'

7. <FRUK:>tansvärt svårt språk men ja har gett mej

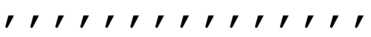

dreadful-ADV difficult language but I have-PRS give-SUP I.OBJ 'TERRibly difficult language but damn me I have'

8. fanken ((banging gesture with fist)) på att <ja ska r, r, r,

devil on that I shall

'made up my mind that I will'

9. kunna> läsa (.) en artikel i Zhen Min Zhe Bao, can.INF read-INF an article in NEWSPAPER-NAME((in Chinese)) 'be able to read an article in Zhen Min Zhe Bao,'

10. de vill säja Folkets Dagblad. (...) that will say NEWSPAPER-NAME ((translated into Swedish)) 'that is to say The People's Daily News.'

11. R: okej. okay. 
12. S: men de kan ja inte än.

but that can I not yet

'but I can't do that yet.'

13. R: men tids nog kanskei

but time-GEN enough perhaps

'but with time perhapsi'

In line 2, Svensson reacts to the proposal that he can "speak" many languages, producing the verb tala in the format $x$ - $\stackrel{a}{-}-x$. His response is that he can "use" about ten languages, which arguably is a relativization tuning down the suggestion; presumably, he means that he can use his ten languages for certain purposes, but that it would be an exaggeration to claim that he could "speak" them across the board of all possible situations. What S means exactly is of course difficult to tell; the expansion is characteristically brief and semantically underdetermined (what does 'being able to use a language' mean more precisely?). The function of $x$ - $\stackrel{a}{-}-x$ is reduced here only to relativizing and diminishing certain aspects of the verb tala 'speak'. Note however that the expansion following the initial $x$ - $\stackrel{a}{-}-x$ part acknowledges the second component of the interviewer's claim, namely, the number of languages S masters (to some degree). The following lines 4-13 are topically related to the first question-answer pair, but they do not pursue the discussion of the situated meaning of $x$. Participants seem to rely on having reached a sufficient level of intersubjectivity to continue on with the discussion.

Whereas in Extract 2 the participants are basically (and implicitly) talking about how knowledgeable one has to be in order to be qualified for the description "speaking a language", in the next example they talk about the extent and depth with which one should talk with another person for the communication to count as "talking in depth about a given topic with a particular interlocutor". In the background there is the question whether Svensson, who is still the main character, is nowadays at all "on speaking terms" with another person (called Dahl below). 
The immediate co-text for the talk in Extract 3 is that Rosenberg, the interviewer, has just played back an old recording from a discussion between Svensson and another very wellknown politician, a former prime minister (Dahl). This discussion took place in the autumn of 1994, the night after the Swedish referendum about joining the EU. Svensson and Dahl were the leading figures on the two opposed sides. During this nightly exchange, the two had fallen out on each other in a rather remarkable way, considering that their conversation was broadcast on the radio. At one moment (played back in the talk-show of 2014) Svensson roared at Dahl: "shut up, Jens Dahl” (Sw. håll truten, Jens Dahl), which was responded to by Dahl by recommending Svensson to go home and go to bed to get some rest. Thereby Dahl had insinuated, Svensson argues, that he (Svensson) had had a hang-over. This is the topic of Svensson's ironic remark in lines 1-2 (“a great rhetorician"). This move is followed by Rosenberg's (the interviewer) exclamation som $d u$ '(just) like you' (line 3), followed by the quote håll truten 'shut up' (in the imperative), the words Svensson had used in the debate with Dahl.

(3) PRATAT OM Å PRATAT OM (TV talk-show with the same participants as in (2))

1. S: han e en stor eh (.) retoriker å kan ta vilka grepp he is a big PRT rhetorician and can take what grip.PL 'he is a great uh (.) rhetorician an' can take measures'

2. som helst

as preferred

'of any kind'

3. R: som $\uparrow \mathrm{DU}$. håll 个trüten. as you hold.IMP jaw-DEF 'just like YOU. shut up.'

4. S: jạ ja ${ }^{\circ}$ visst ${ }^{\circ}$ yeah yeah ${ }^{\circ}$ sure ${ }^{\circ}$

5. R: du, har ni pratat om de här nån gång you have-PRS you.PL talk-SUP about this here some time 
'hey, have you talked about this at any time'

6. S: de HẠ:R Vi faktist allså, prätat om å pratat om $1,1,1,1,1,1,1,1,1,1,1,1,1,1,1,1,1,1,1$, that have-PRS we factual-ADV PRT talk-SUP about and talk-SUP about 'indeed we HAVE after all, talked about an' talked about but'

7. men vi har pratat me varandra å så som sagt

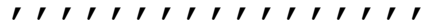

but we have-PRS talk-SUP with each-other and so as say-SUP 'but we have talked with each other and as I said I have'

8. ja har respekt för honom $i$ en de:l avseenden, I have-PRS respect for he-OBJ in a part respect-PL 'I have respect for him in some ways,'

9. =ukraina har han varit ganska vetti 'o̊ så där va ${ }^{\circ}$, Ukraine have-PRShe be-SUP quite sensible and like that what '=Ukraine he has been fairly reasonable ${ }^{\circ}$ and such like ${ }^{\circ}$,'

10. sen finns de andra avseenden,=ja skulle hellre ha

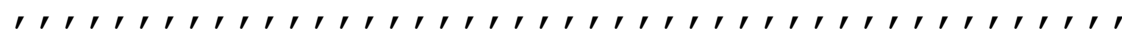
then exist-PRS it other-PL respect-PL I would rather have 'then there are other aspects, =I would rather prefer another'

11. en annan försvarsminister ${ }^{\circ}$ men ja kan ha respekt $r, r, 1,1,1,1,1$,

an other defence-minister $I$ can have respect 'minister of defence 'but I can have respect'

12. för honom. ${ }^{\circ}$

for he-OBJ

'for him ${ }^{\circ}$,

Rosenberg's question in line 5 deals with whether Svensson and Dahl have talked about their public verbal fight at some later occasion. Svensson's $x$ - $a-x$ retort is unusual in that it cites a part - pratat om 'talked about' - which is not a constituent in the source utterance (line 5); there, pratat is the tensed predicate verb and om 'about' is a preposition taken from another constituent, i.e. what is usually analyzed as a prepositional object (here: om de här 'about this'). While $x$ - $\stackrel{\circ}{-}-x$ has quite a wide applicability with regard to what kinds of source 
$x: \mathrm{s}$ it can take, this is an unusual example also from this point of view. The reason for Svensson to use it in this way is arguably that the problem lies in the combination of the verb and its implied object. He has been on speaking terms with Dahl after the infamous verbal fight (line 6), and "can have respect for" him (lines 7-11), but the two have apparently not spoken about the specific event, at least not in any depth.

This episode is arguably delicate for Svensson to handle; after all, he has told a former prime minister to "shut up" in a non-private discussion broadcast on the radio, hardly a very respectful conduct. And now this has been played once again to a TV audience. It is therefore not a surprise that Svensson is keen on ensuring (twice) that he "has/can have respect" for Dahl (lines 8 and 11), although he also suggests that the latter is a "great rhetorician" (line 1), which was presumably not meant as a praise. The keenness to smoothe over a problem may also come to the fore in Svensson's initial, straightforward response to Rosenberg's question, "indeed we have" in line 6. It is only after this acknowledgement that Svensson initiates a concession with $x$ - $\stackrel{a}{-} x$, as if trying to correct the first, immediate version of his reply which could have been interpreted as stating that Svensson and Dahl have in fact been talking about the verbal fight. There are thus many indications that the situation at hand involves mixed feelings, a good breeding-ground for $x$ - $\stackrel{a}{-}-x$.

The delicacy of this particular episode is also shown in Svensson's non-verbal conduct. One should know that he is a self-confident person who speaks his mind without hesitations in the interview. Like any other speaker, he vacillates between gaze contact and looking away, but here he averts gaze only for very brief moments. However, during the production of lines 6-11 in Extract 3, Svensson avoids gaze contact with the interviewer for most of the time. These lines belong to the expansion of the $x-\stackrel{a}{a}-x$ construction, where the speaker is balancing the two interpretations at stake. During the very start of his response turn (beginning of line 6), where the immediate reaction is produced, he looks at his interlocutor, 
and he resumes gaze contact when he has arrived at the location where the "corrected version" is produced, pratat me varandra 'spoken with each other' in line $7 .{ }^{9}$ Svensson's behavior may indicate that he would rather avoid talk about the 1994 radio event, and instead tries to "scale it down" (cf. Section 6 below) from 'talking about' the delicate issue to 'talking with each other' (line 7).

The third example (Extract 4) from the Svensson-Rosenberg talk-show follows on a fairly long sequence that we have omitted for reasons of space. The gist of this sequence was that Svensson, who was a young liberal during the 60's, was back in those times publicly arguing against marriage and for free love. However, his own two marriages broke up, partly as a consequence of infidelities that the spouses could not handle.

In (4), the interviewer asks about the "political idea" behind "free relationships" (lines 1-2), which of course invokes various interpretations of "politics" and "political”. Svensson's lengthy response (lines 3-16) revolves around the relation of marriage (a personal relation between two individuals) and politics, something that concerns the relationship between a private sphere and a public or societal policy. Marriage is both (a) a political issue for governments, parliaments, the church, etc., for regulating how individuals share lives together, especially as regards handling sexuality, cohabiting etc. in personal relations, and (b) an individual, everyday issue: parties (spouses) must regulate their life together, take a common stance to cohabitation with or without marriage, monogamy vs polygamy, extramarital relations, attitudes to homosexuality and other forms of sexual relationships.

(4) POLITISK Å POLITISK (TV talk-show with the same participants as in (2-3)) 1. R: e de (.) va e den polítiska tanken bakom de här me is there (.) what is the political idea behind this about

2. fria- (.) eller ett fritt förhållande, ${ }^{\circ}$ eller va- ${ }^{\circ}$ free- (.) or a free relationship, ${ }^{\circ}$ or what- ${ }^{\circ}$

3. S: ja, polittisk å polítisk de e ju en de- vikti del av well, political an' political it is PRT a pa-important part of

4. livet hur man lever allså,=de e klart att att life how one lives one's life after all, it is clear that that 
5. privatlivet e omgärdat av en mängd lagar å sånt va private life is enclosed by many laws an' such, isn't it

6. 'å då tyckte man varför ska staten lägga sej i (.) hur ${ }^{\circ}$ an' then ${ }^{\circ}$ one thought that why should the state interfere into (.) how

7. man lever genom att ha ett speciellt äktenskap å sånt one lives one's life by having a special marriage an' such like,

8. va, =nu har vi ju äktenskapbegreppet utvidgats now the concept of marriage has PRT been extended

9. Väldeliga, =nu kan även även homosexuella gifta sej à enormously, = now even homosexuals can get married and

10. sånt vilket ja tycker e jättebra å iåme de så de har such which I think is super good an' with that they have

11. ju samtidit s'attsäja tunnats ut, = de e inte de här PRT simultaneously so to speak been attenuated, $=$ it isn't this

12. (.) gamla kristna äktenskapet lika mycke utan de e de (.) old Christian marriage to the same extent but it is it

13. e mer en (.) praktisk avtalsform på nå sätt, ja ja is more a (.) practical form of contract in some way, I I

14. tycker inte de ska avskaffas helt men ja har full don't think it should be abolished altogether but I have complete

15. förståelse för dom som som (.) inte vill ha den understanding for those who who (.) don't want to have that

16. formen. form.

Svensson uses $x$ - $\stackrel{a}{-}-x$ to argue for the need for freedom of choice for the persons involved, the need for personal agreement between spouses (or individuals in local communities), while there is no need for legal regulations. Hence, the reactive construction points to a difference between officially formulated, regulated policies and more covert, grass-roots policies.

What happens in Extracts 2-4 is that one of the parties, the interviewer, proposes a characterization of circumstances in a first turn, and the other party, the interviewee, reacts to a specific part $x$ of the characterization by using the format $x-\stackrel{a}{-}-x$. The reaction indicates problems with the item $x$, and implicates tensions in the intersubjective understanding regarding that item in a specific interactional micro-situation. By using a given label $x$, such as politiska 'political' in (4), the interviewer proposes the terms for the ensuing talk, but the 
interviewee then decides that these terms are only partly acceptable, displayed in the format $x$ $\stackrel{\circ}{a}-x$.

For speakers of Swedish, the construction $x-\stackrel{a}{-}-x$ is a resource through which the conditions of ensuing talk can be called to question by focusing on the issue that is specifically problematic in them. In such problematizing events, the speaker makes a metalinguistic move (Norén and Linell 2007), drawing attention to different meaning potentials associated with a certain word or phrase, and then, in the expansion of $x-a-x$, the speaker chooses an aspect of meaning which stands out as relevant in the situation for himself and thereby serves as an acceptable point of departure for further talk on the topic. Hence, there is both a subjective and an intersubjective angle to the $x-\stackrel{a}{-}-x$ construction. To raise an issue of meaning potentials is to refer to the shared linguistic knowledge within a speech community - a knowledge that should be accessible for both the speaker and listener(s). Hence, whatever the problem with $x$ is, all the parties involved could, in the end, be able to access the possible problem with $x$ in a given situation. At the same time, the use of $x$ - $a-x$ signals that a certain understanding of $x$ is preferred. What is left open, in the end, is whether this subjective stance to $x$ can accommodate the prior stance of the producer of the source $x$; nevertheless, it is evident that some possible meanings and stances that can be associated with $x$ need to be cancelled out in the interactional micro-situation. $X$ - $\stackrel{a}{-}-x$ is a means of making the coparticipant aware of this need.

Let us finally attend to another aspect of intersubjectivity, namely the participation frameworks in which $x$ - $a-x$ tends to occur. Despite the fact that it embodies a reaction to a stance that cannot be accepted in its entirety, the construction is typically used in turns that are themselves monologically organized, almost as if to block off any further response from the other party (who originally lauched $x$ ). It is the same speaker who both introduces and completes the $x$ - $\stackrel{a}{a}-x$ turn, and the situated appropriateness of $x$ is seldom pursued any further. 
Thus, the speaker normally gets the last word in and through the turn in which $x-\stackrel{a}{-}-x$ is used, and therefore $x-\stackrel{\circ}{a}-x$ could be heard as a marker of a subjective stance. On the other hand, the construction is a reaction to prior talk, and the speaker voices (usually two) different perspectives that mirror what occurs in the language community at large. These latter aspects reflect, of course, intersubjectivity. ${ }^{10}$

There are partial exceptions from the characterization just proposed. In Extract 5, also from a dyadic talk-show televised in Sweden, in this case in 2015, we have a journalist (I) interviewing a retired financial and industrial leader, whom we here call Carl Anderson (A). The interviewer, in line 1, suggests that A's stressful life led him to be careless (slarva) with sleeping and eating:

(5) SLARVADE Å SLARVADE (TV talk-show with a retired industrial leader (A) and an interviewer (I))

1. I: du slärvade me sömnen: eh (.) slarvade me maten you were careless with sleep uh (.) careless with food

2. (.)

3. A: jae: (0.3) slarvade å slarvade, 'o de låter well, (0.3) careless an' careless ((lit. 'was careless', i.e. a verb)), 'that sounds

4. ungefär $\left[\right.$ som $^{\circ}$ almost $a s^{\circ}$

5. I: [men de va lite sömn å mer mati but there was little sleep an' more food

6. A: (de) blev ju de

(it) became PRT like that

7. (1.0) ((A looks at I; laughter))

8. A: $a:$

yes

9. A: ja $[e$

I am

10. I: [du brände diyou burnt you-

11. A: ja e inte ensam i de här, de e många som har råkat ut I am not alone in this, there are many who have ended up

12. för de här here

13. I: du brände ditt ljụs i båda ändar ofta 
you burnt your candle at both ends oftentimes

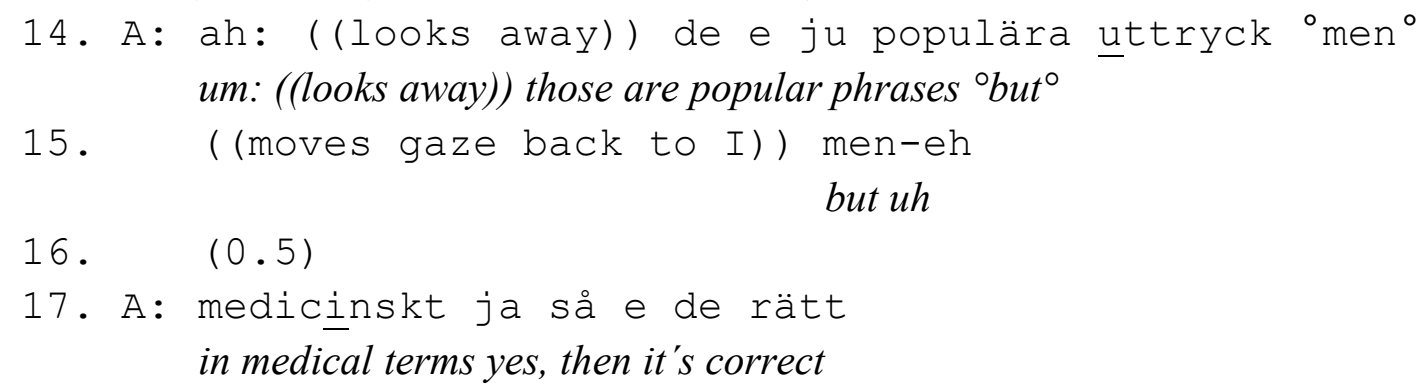

The use of the verb slarva 'be careless' may, in this case, be heard as accusing the addressee of having a weak moral feeling of responsibility for his own health. This is probably what $\mathrm{A}$ is on the verge of objecting against, when his $x$ - $\stackrel{a}{-}-x$ expansion ("that sounds almost as") in lines 3-4 is interrupted by the interviewer. What the interviewer does in line 5, and later, is to pursue his own version, despite A's attempts to modify the picture. Anderson defends himself by pointing out that many individuals end up in the same predicament (provided, presumably, they have A's kind of job) (lines 11-12), and that we are faced with a “medical" outcome (line 17), both arguments that serve to diminish his personal responsibility. Anderson also tries to ward off the interviewer's position by suggesting that his metaphor of "burning one's candle at both ends" is just a "popular phrase" (line 14), thus arguably trying to bring the exchange back to serious topics, such as the kind of hard work he has shared with many. We have brought this excerpt up, because it shows that the issue of situational appropriateness of meaning (here: the justification for the use of the verb slarva) may indeed sometimes be pursued by both participants in an interactive fashion - not least in a debating interview genre. In (5), speaker A is able to put an end to the discussion only in line 17 , which is far beyond his $x$ - $\stackrel{a}{-x}$ turn in line 3 . Accordingly, the expansion part of (5), roughly lines $5-17$, is co-constructed, including insisting moves from the producer of the original $x$. In Excerpts 2-4, by contrast, we have seen one single speaker constructing the expansions by himself, but the expansions embody an "internal dialogue" between two 
different voices of his mind. (Note, however, that in Excerpt 2, the two speakers are both involved in mutual alignment in a sequence following the expansion, lines 11-13.)

\section{CONCLUDING DISCUSSION}

In this attempt to explore intersubjectivities in interpersonal interaction we have refrained from embarking on a philosophical discussion of intersubjectivity, subjectivity and objectivity (as is so common in social science) ${ }^{11}$, and instead gone straight on to an empirical study of a few sense-making strategies deployed in mundane discourse. Our analyses confirm that $x$ - $\stackrel{a}{-} x$ is a grammaticalized, i.e., conventionalized, resource in Swedish for problematizing a situated use of some expression or wording $x$ in a prior utterance. The construction can be used for regulating partial intersubjectivity and clarifying situated meanings in interactions. Moreover, it can contribute to participants' metalinguistic deliberations of meaning potentials of words and phrases in the language at hand (Norén and Linell 2007). Words usually cover a spectrum of semantic aspects, and it is up to the interlocutors to foreground some of these while backgrounding others in situated use. In many cases the meaning potentials involve oppositions between semantic aspects, e.g., in the case of flytta 'move', between a basic meaning ('change one's residence or other position') and a connoted aspect (the movement is voluntary). Usually, the two aspects are both valid, but in some instances the basic aspect is the only one that is foregrounded, for example, as G's utterance may be understood in Excerpt 1.

In a large number of cases word meanings contain a scalar dimension, and $x$ - $\stackrel{a}{-}-x$ can have the effect of relativizing and scaling down the full meaning in its situated use. For example, speaking a language can mean something like 'being able to express any thoughts and feelings comprehensively and sensitively in that language', an interpretation that the $x$ - $\stackrel{a}{-} x$ speaker in Extract 2 is warding off, in favour of a weaker interpretation, probably more like 
'being able to use some phrases in phatic functions or about practical matters' (although the speaker is hardly precise about this). Similarly, being on speaking terms might mean something like 'analyzing or even solving disagreements on important (e.g. political) issues', while the $x$ - $\stackrel{a}{-} x$ speaker in Extract 3 seems to reduce it roughly to 'being able to exchange utterances at least superficially in a civilized and rational manner'. ${ }^{12}$

The $x$ - $\stackrel{a}{-} x$ construction is always second-positioned, most often other-initiated (although also same-speaker uses occur) and, in that case, oriented to a source in the prior speaker's contribution. It deals with different ways of making sense of $x$ in situ. The clarifications of the nature of these differences usually remain brief and implicit in their contexts of use. After all, we are faced with people's everyday practices, not with attaining absolute terminological precision as in certain scientific genres. However, our talk-show data involve more expanded clarifications than in many other conversational settings, thus showing more clearly all the complexities which can be present in intersubjective work.

It is important to point out that a speaker's initiative to take a new turn in conversation is in general typically a response to the other's prior contribution. Thus, a participant's stancetaking in a dialogical exchange is largely an action in a situation that is jointly co-ordinated and at least partly shared. A single contribution within a reasonably coherent sequence presupposes an understanding of the prior contribution(s), and, by making relevant responses, interlocutors produce a weave of interactional moves which contribute to an experience of intersubjectivity. The use of $x$ - $\stackrel{a}{-}-x$ is an eminent example of this, bringing the intersubjective work to the foreground when dealing with the relevance of an attribute or characterization in an interactional micro-situation.

The use of $x-\stackrel{a}{a}-x$ draws upon tensions between different aspects of the meaning potential of $x$, divergences that ultimately reflect differences between segments of the language community and their divergent communicative needs in different situations. Sense-makings in 
the real world involve opposites, contradictions and conflicts. The user of $x-\stackrel{a}{a}-x$ is seeking acceptance of the point that different positions in society may be relevant in the specific situations and may call for different interpretations of $x$. The practice has thus concessive features.

One might think of $x$ - $\stackrel{a}{-}-x$ events as negotiating limitations on intersubjectivity. But it is important to understand intersubjectivity as partial and dynamic (Linell 2009a, 2016). Many intersubjectivities cannot be reduced to simple agreements or disagreements among interlocutors. Our data point to the fact that intersubjectivities are replete with multivoicedness and oppositions between stances, both in the community at large and in the situated exposition by the single individual speaker. ${ }^{13}$ In practice, however, participants in $x$ $\stackrel{\circ}{a}-x$ events tend to juxtapose only two interpretations, which are presented as opposed to each other (cf. the two conjoined $x$ :s appearing in the initial $x$ - $\stackrel{a}{a}-x$ segment). The $x$ - $\stackrel{a}{a}-x$ turn never expresses one singular and stable stance on the part of the speaker; on the contrary, the situated use of $x$ is seen as both appropriate in some aspects, and as inappropriate in other aspects. There is an "on the one hand vs. on the other hand" structure to every $x$ - $\stackrel{a}{-}-x$ event. At the same time, however, $x$ - $\stackrel{a}{-}-x$ events do not exhaust possible understandings.

What interlocutors do in episodes that involve $x$ - $\stackrel{a}{-x}$ is to provide "sufficient clarifications" (of $x$ and its contribution to the situated discourse) and thereby also to achieve "sufficient understandings" for the "practical purposes" at hand in the situation (cf. references to Schütz and Garfinkel in Section 1). Yet, in discussions of intersubjectivity among interaction analysts, it is not uncommon that parties to interaction are portrayed as being engaged in achieving "socially shared cognition", and that this is what should be meant by intersubjectivity (Schegloff 1991, 1992). But communication is not about achieving completely shared understandings (agreements, consensus, etc.), but involves sufficient understandings for current practical purposes. As human beings we have been thrown into a 
heterogeneous world, and we have to communicate under the conditions that individuals and groups quite often hold different ideas and take divergent stances. Yet, parties to any interaction are faced with the need and challenge to work at making (some) sense together, sometimes from disparate points of departure and with their possibly diverging personal and cultural backgrounds. This goes well together with a view of intersubjectivity as a situated, temporarily sustained and only partially shared experience (Rommetveit 1974), and which is based on interactivity, rather than on shared cognition.

\section{ACKNOWLEDGEMENTS}

We gratefully acknowledge useful comments by three anonymous referees. Per Linell's work on this paper was supported by a grant to LinCS from the Swedish Research Council (3492006-146). Jan Lindström has contributed as a member of the Finnish Centre of Excellence in Research on Intersubjectivity in Interaction (intersubjectivity.fi).

\section{APPENDIX}

Transcription symbols

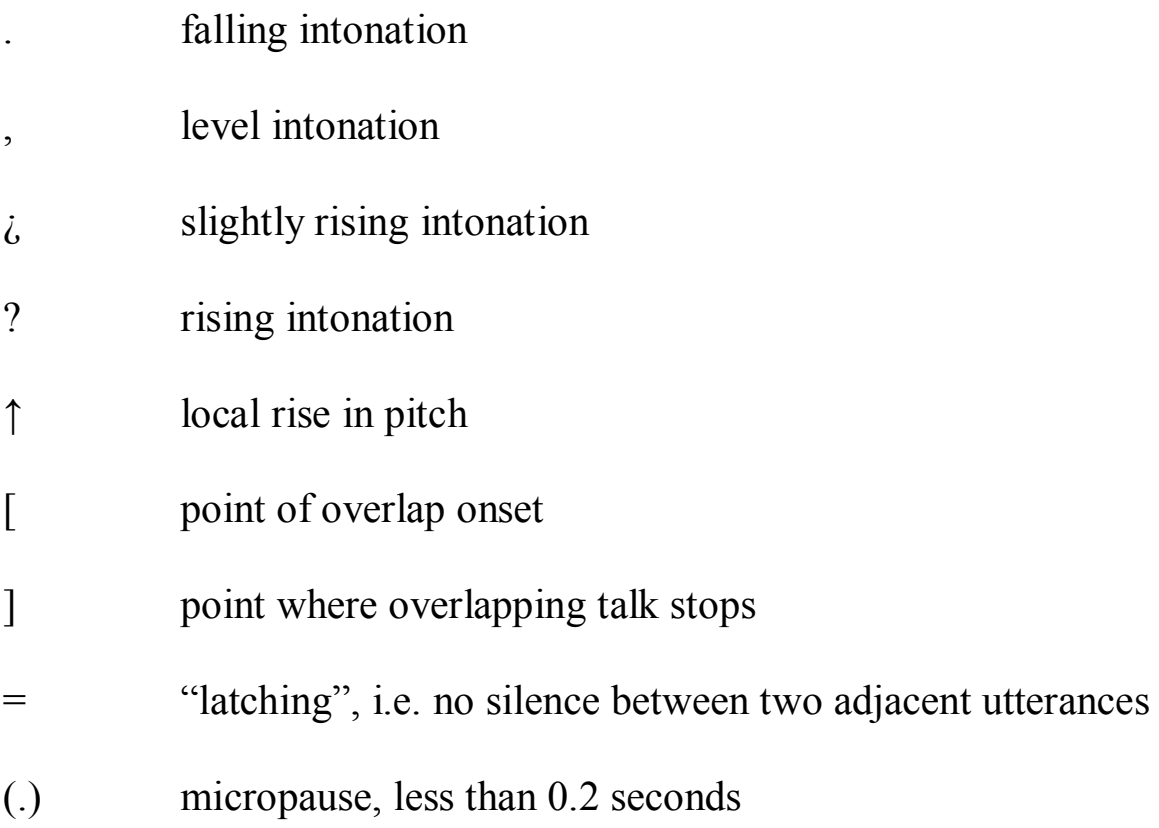


(0.5) silences timed in tenths of a second

$>\quad$ talk inside is at a faster pace than the surrounding talk

$<>\quad$ talk inside is at a slower pace than the surrounding talk

va- cut off

va: lengthening of a sound

va emphasis indicated by underlining

VA higher volume indicated by capitals

${ }^{\circ} \mathrm{va}^{\circ} \quad$ talk inside is more quiet than the surrounding talk

"va" altered voice quality

(va) uncertain transcription

?: $\quad$ uncertain speaker identification

,,,, $\quad$ series of commas indicate averted gaze

\section{REFERENCES}

Auer, Peter. 1996. The pre-front field is spoken German and its relevance as a grammaticalization position. Pragmatics 6(3), 295-322.

Bolden, Galina. 2009. Beyond answering: repeat-prefaced responses in conversation. Communication Monographs 76(2), 121-143.

Couper-Kuhlen, Elizabeth \& Sandra A. Thompson. 2005. A linguistic practice for retracting overstatements: 'Concessive Repair'. In Auli Hakulinen \& Margret Selting (eds.), Syntax and lexis in conversation, 257-288. Amsterdam: John Benjamins. 
Fillmore, Charles J., Paul Kay \& Mary C. O’Connor. 1988. Regularity and idiomaticity in grammatical constructions: the case of let alone. Language 64, 501-538.

Finkbeiner, Rita. 2012. Naja, normal und normal. Zur Syntax, Semantik und Pragmatik der xund-x-Konstruktion im Deutschen. Zeitschrift für Sprachwissenschaft 31, 1-42.

Fried, Mirjam \& Jan-Ola Östman. 2005. Construction Grammar: a thumbnail sketch. In Mirjam Fried \& Jan-Ola Östman (eds.), Construction Grammar in a cross-language perspective, 11-86. Amsterdam/Philadelphia: John Benjamins.

Garfinkel, Harold. 1967. Studies in ethnomethodology. (Prentice-Hall). New ed. 1984 [1992]. Cambridge: Polity Press.

Heritage, John. 1984. Garfinkel and ethnomethodology. Oxford: Polity Press.

Kendon, Adam. 1967. Some functions of gaze direction in two-person conversations. Acta Psychologica 26, 22-63.

Labov, William \& David Fanshel. 1977. Therapeutic Discourse. New York: Academic Press. Lauerbach, Gerda. 2004. Political interviews as hybrid genre. Text 24, 353-397.

Levinson, Stephen. 1979. Activity types and language. Linguistics 17, 365-399. (Also in Paul Drew \& John Heritage, (eds.) 1992. Talk at Work, 66-100). Cambridge: Cambridge University Press. 
Lindström, Jan. 1999. Vackert, vackert! Syntaktisk reduplication i svenskan. [“Nice, nice! Syntactic reduplication in Swedish"]. Helsinki: Studier i nordisk filologi, 77.

Lindström, Jan. 2006. Grammar in the service of interaction: exploring turn organization in Swedish. Research on Language and Social Interaction 39(1), 81-117.

Lindström, Jan. 2008. Tur och ordning: introduktion till svensk samtalsgrammatik. ["Turns in order: introduction to Swedish conversational grammar"]. Stockholm: Norstedts Akademiska Förlag.

Lindström, Jan \& Per Linell. 2007. Roli å roli: x-och-x som samtalspraktik och grammatisk konstruktion. ["Funny and funny: $\mathrm{x}$-and-x as a conversational practice and a grammatical construction"]. In Elisabet Engdahl \& Anne-Marie Londen (eds.), Interaktion och kontext: nio studier av svenska samtal [“Interaction and context: nine studies of Swedish conversations"], 19-89. Lund: Studentlitteratur. [Reprinted in Linell 2011: 88-161.]

Linell, Per. 2009a. Rethinking language, mind and world dialogically: interactional and contextual theories of human sense-making. Charlotte, NC: Information Age Publishing. Linell, Per. 2009b. Grammatical constructions in dialogue. In Alexander Bergs \& Gabriele Diewald (eds.), Contexts and Constructions, 97-110. Amsterdam: John Benjamins. 
Linell, Per. 2011. Språkande: samtal, språk och grammatik. ["Languaging: talk, language and grammar"]. (Studies in Language and Culture, 17). Linköping: Department of Communication and Culture.

Linell, Per. 2014. Interactivities, intersubjectivities and language: on dialogism and phenomenology. Language and Dialogue 4, 165-193.

Linell, Per. 2016. Intersubjectivity in Dialogue. Forthcoming in Edda Weigand, (ed.), Language and Dialogue: A Handbook of Key Issues in the Field. Informa UK Limited/Routledge.

Linell, Per \& Christine Mertzlufft. 2014. Evidence for a Dialogical Grammar: reactive constructions in Swedish and German. In Susanne Günthner, Wolfgang Imo \& Jörg Bücker (eds.), Grammar and dialogism: sequential, syntactic and prosodic patterns between emergence and sedimentation, 79-108. Berlin: de Gruyter.

Luckmann, Thomas. 2002. On the methodology of (oral) genres. In Per Linell \& Karin Aronsson, (eds.) Jagen och rösterna: Goffman, Viveka och samtalet ("Selves and voices: Goffman, Viveka and the conversation"). (SIC, 42), 319-337. Linköping: Tema Kommunikation.

Myrendal, Jenny. 2015. Word meaning negotiation in online discussion forum communication. University of Gothenburg: Department of Philosophy, Linguistics and Theory of Science. 
Norén, Kerstin \& Per Linell. 2007. Meaning potentials and the interaction between lexis and contexts: some empirical substantiations. Pragmatics 17, 387-416.

Rommetveit, Ragnar. 1974. On message structure. London: Wiley.

Schegloff, Emanuel A. 1979. The relevance of repair to syntax-for-conversation. In Talmy Givón. (ed.), Syntax and Semantics, Vol. 12: Discourse and Syntax. New York: Academic Press. 261-286.

Schegloff, Emanuel A. 1991. Conversation Analysis and socially shared cognition. In Lauren Resnick, John Levine \& Stephanie Teasley (eds.), Perspectives on socially shared cognition, 150-171. Washington, DC: American Psychological Association.

Schegloff, Emanuel A. 1992. Repair after next turn: the last structurally provided place for the defense of intersubjectivity in conversation. American Journal of Sociology 95, 1295-1345.

Schegloff, Emanuel A. 1996. Turn organization: one intersection of grammar and interaction. In Elinor Ochs, Emanuel A. Schegloff \& Sandra A. Thompson. (eds.), Interaction and grammar, 52-133. Cambridge: Cambridge University Press.

Schütz, Alfred. 1962. Commonsense and scientific interpretations of human action. In Alfred Schutz, Collected papers, Vol. 1, 3-47. The Hague: Martinus Nijhoff. 
Traugott, Elizabeth C. 2014. Intersubjectification and clause periphery. In Liselotte Brems, Lobke Ghesquière \& Freek Van de Velde (eds.). Intersubjectivity and intersubjectification in grammar and discourse, 7-27. Amsterdam: John Benjamins.

\footnotetext{
${ }^{1}$ We will sometimes use the terms "interactivities" and "intersubjectivities" in the plural, since we assume that both interactivity and intersubjectivity occur in different kinds and with varying comprehensiveness.

${ }^{2}$ In this paper, we will not study self-responsive cases with this construction, but see Lindström and Linell (2007).

${ }^{3}$ This example, among many others, was analysed at some length in Lindström and Linell (2007).

${ }^{4}$ For comparisons between this construction and $x$ - $\stackrel{a}{-}-x$, see Myrendal (2015).

${ }^{5}$ The pre-front and post-end fields (Auer 1996; Schegloff 1996; Lindström 2006), i.e. utterance segments that are not syntactically integrated in the core clause, are the "dislocated" "peripheries" (or “edges") that Traugott (2014:9) also calls "clause-external”. The pre-front field could be further subdivided. Thus, there seems to be a first slot for response particles, discourse markers etc., and a (following) slot for "dislocated" content words, among which $x$ $\stackrel{\circ}{a}-x$ may be included. In Excerpt 1, Speaker A prefaces his $x$ - $\stackrel{a}{-}-x$ utterance with a response particle, here an elongated and hesitating ja:e 'yes:', translated by us as 'well'. This is quite a common feature (cf. $1: 1.7 ; 4: 1.3$ ). Such units are typically projective, i.e., they project a complex answer, but they are of course responsive too, linking the answer to the previous problematic question (or assertion, as in (5)).
} 
${ }^{6}$ In exceptional cases there are truncated variants, in which speakers or writers (in electronic discourse) interrupt themselves already after the $x-\stackrel{a}{a}-x$ segment (or put this expression within parentheses in writing), thus omitting the expansion. Norén and Linell (2007:395) give the following example from an Internet blog: Jag var fortfarande i den bästa bilen (bil och bil) vi stannade för att bada [...] 'I was still in the best car (car and car) we stopped to take a swim [...]'. Evidently, the writer wants to imply that the vehicle was in such a bad condition that it was questionable if it could be called a "car". Such uses indicate that the construction may be so conventionalized that the initial segment alone communicates the point that the situated use of $x$ is not quite appropriate.

${ }^{7}$ That the interviewees have stepped down from their previous more or less powerful positions will have consequences for the form and content of the interviews. They are not like news interviews with politicians still in office. However, questions leading to $x$ - $\stackrel{a}{-}-x$ responses seem to be overrepresented in both regular news interviews and "our" talk-shows. Our data have certain similarities with those of Lauerbach (2004).

${ }^{8}$ See references above.

${ }^{9}$ In the majority of our examples, there is gaze contact with the interlocutor during the turninitial $x$ - $\stackrel{a}{-} x$ segment, which thus contradicts the generalization that speakers tend to look away during turn beginnings, especially in "long utterances", which also $x$ - $\stackrel{a}{-} x$ tend to initiate (cf. Kendon 1967:35).

${ }^{10}$ See the references given above, especially in Section 3.

${ }^{11}$ See Linell $(2014,2016)$ and references there. In general, we are sceptic about the fruitfulness of classifying knowledge, assumptions and understandings into the two categories of subjectivity and intersubjectivity, if these are assumed to be acquired, held, expressed or achieved by one vs. two or more human sense-makers, respectively. Rather, human sensemaking always involves degrees of intersubjectivity. 
${ }^{12}$ For more examples of scaling down by means of $x$-åa-x, see Norén and Linell (2007) and Lindström and Linell (2007). See also Couper-Kuhlen \& Thompson (2005:269) on scalarity.

${ }^{13}$ This also holds for self-responsive uses of $x$ - $\stackrel{a}{-}-x$, when a speaker reacts to his or her own prior use of a particular expression. For many such cases, see Lindström \& Linell (2007). 